\title{
Translanguaging in Early Childhood Education in Luxembourg: From Practice to Pedagogy
}

\section{Claudine Kirsch and Claudia Seele}

\begin{abstract}
An inclusive translanguaging pedagogy aims to promote learning and participation by drawing on the learners' entire semiotic repertoire. The focus of this chapter are the translanguaging practices of four early years practitioners in Luxembourg. We analyse the deployment of their linguistic repertoire, their reasons for translanguaging, and the ways in which their practices contributed to inclusion and participation. We found that the practices comprised using linguistic resources dynamically, translating, and 'home languaging,' and depended on the practitioners' pedagogical stance. We argue that multilingual practices need to be embedded in a reflexive translanguaging pedagogy in order to enhance inclusion.
\end{abstract}

\section{Keywords}

Early childhood education $\cdot$ Luxembourg $\cdot$ Translanguaging pedagogy $\cdot$ Inclusion

C. Kirsch $(\bowtie)$

University of Luxembourg, Esch-sur-Alzette, Luxembourg

e-mail: claudine.kirsch@uni.lu

C. Seele

RAA Mecklenburg-Vorpommern e. V., Waren (Müritz), Germany

e-mail: claudia.seele@raa-mv.de

(C) The Author(s) 2020

J. A. Panagiotopoulou et al. (eds.), Inclusion, Education and

Translanguaging, Inklusion und Bildung in Migrationsgesellschaften, https://doi.org/10.1007/978-3-658-28128-1_5 


\section{Introduction}

Educational institutions worldwide must cope with increasingly heterogeneous intakes and, therefore, monolingual pedagogical strategies are no longer appropriate. Owing to migration and globalisation, a growing number of children enter these institutions with more varied linguistic repertoires than those of the dominant majority. However, their resources are neither fully acknowledged by education systems nor systematically included in policies, curricula and teaching practices. In education, inclusion refers to 'a process of addressing and responding to the diversity of needs of all children, youth and adults through increasing participation in learning, cultures and communities' (UNESCO 2009, p. 8 f.). The index for inclusion in early childhood education (Booth et al. 2008) provides professionals with concrete strategies that promote inclusion such as recognising cultural and linguistic diversity as a resource, showing respect for children's identities and cultures, and drawing on differences to support play, learning and the participation of all children. Language policies on early language education of the European Commission address the necessity to accommodate children's diverse needs and backgrounds, and promote equal opportunities and social justice (e.g. European Commission 2011). Translanguaging is a central pillar for realising more inclusive, learner-centered, multilingual pedagogies (García and Li Wei 2014; García et al. 2017). As a sociolinguistic and socio-educational concept, translanguaging refers, on the one hand, to the process of deploying one's entire semiotic repertoire to make meaning and communicate and, on the other hand, to pedagogical practices that leverage these processes to support learning and participation (García and Otheguy 2019).

In Luxembourg, multilingualism is an everyday reality (Fehlen and Heinz 2016). Apart from the three official languages - Luxembourgish, French and German - many more are spoken on account of the high proportion of immigrants in Luxembourg. In 2018, $47.5 \%$ of the residents did not have Luxembourgish citizenship (STATEC 2019) and $63.7 \%$ of the four- to six-year-olds spoke a first language other than Luxembourgish (MENJE 2019). Despite this multilingual reality, educational practices were found to hold on to monolingual norms and policies of separating and excluding languages (Christmann 2011; Neumann 2015; Seele 2016). Studies such as PISA, PIRLS and the national épreuves standardisés (standardised tests) have repeatedly shown that academic achievement largely depends on students' socio-economic, migrant and language backgrounds (MENJE 2018). Recent language education policies therefore call for multilingual approaches in early childhood which aim to reduce the persistent inequalities in attainment and promote social justice. 
The present chapter focuses on the translanguaging practices of professionals in early education and a day-care center in Luxembourg. Early childhood education is divided into formal and non-formal institutions (Kirsch and Seele 2020). Formal education for young children is organised within the official school system and comprises a two-year compulsory preschool for four- to six-year-olds and an optional preschool year for three-year-olds called the éducation précoce (early education). In the éducation précoce, teachers and caregivers collaborate and follow the national primary school curriculum. Non-formal educational institutions are a more recent development. They include state or private out-of-school educational institutions such as day-care centers (MFI and SNJ 2013). Professionals adhere to the national framework plan for non-formal education (MENJE and SNJ 2018). In this paper, we analyse the ways in which professionals deploy their semiotic repertoire and examine the extent to which their translanguaging practices contribute to inclusion and participation. The data for the present chapter stem from observations and interviews of the project 'Developing Multilingual Pedagogies in Early Childhood' (MuLiPEC), conducted from 2016 to 2019 by Kirsch.

\section{Translanguaging Pedagogies}

The call for more flexible approaches that open up to the diversity of the children and can accommodate their needs comes from various fields: the index for inclusion (Booth et al. 2008), work on linguistic human rights (Skutnabb-Kangas 1995), and education (Weber 2014), to name a few. 'Multilingual pedagogies' (García and Flores 2012) or 'translanguaging pedagogies' (García et al. 2012, 2017) recognise the existence of multiple linguistic resources in educational institutions and attempt to leverage students' unitary semiotic system to support meaning-making and learning (García et al. 2017). This resource-based pedagogy places the learners at the center, values their linguistic and cultural practices, and offers them some choice over their language use. The transglossic learning arrangements challenge dominant monolingual practices and equalize positions of learners' by allowing them to deploy their multilingual repertoires flexibly.

To contribute to the implementation of the pedagogy and help practitioners conceptualise the main aspects, García et al. (2017) identified three interrelated elements; stance, design and shifts. The stance refers to the teachers' commitment to embrace multilingualism, draw on students' repertoires, and consider their languages as part of a unitary system rather than as isolated and bounded entities. The design refers to the curriculum and activities that integrate children's diverse 
linguistic and multimodal resources and enable children to connect home and school languages. The shifts denote the teachers' deviations from the design and the flexible ways in which they adapt to the children's needs.

Studies in monolingual, bilingual and multilingual early years settings have identified various purposes and benefits of translanguaging: facilitating communication and meaning-making, promoting participation and learning and supporting the children's socio-emotional development and multilingual identities (García 2011; Garrity et al. 2015; Kirsch 2017). In these studies, translanguaging was transformative in that it changed individuals and made teachers develop inclusive practices which valued all languages and challenged dominant monolingual practices. This was the case when teachers raised the status of minority languages, drew on the children's varied funds of knowledge for learning, and designed collaborative tasks where children used their linguistic repertoires flexibly (Gort and Sembiante 2015; Mary and Young 2017; Palviainen et al. 2016).

Some studies shed light on the relationship between translanguaging and inclusion. Studying translanguaging in a bilingual education programme in a secondary school in Sri Lanka, Wijesekera et al. (2018) found that the teachers generated inclusion through creating feelings of solidarity and interdependence between students of two ethnicities, who had historically lived in separation and anxiety. This led to respect and the feeling of being a member of a community. Examining the use of multiple languages in a Dutch-medium secondary school in Brussels, Jaspers (2015) concluded that this practice may reinforce traditional language hierarchies. While abiding to the school's monolingual language policy, the teachers, Mr S in particular, reverted at times to French and the children's home languages including Turkish and Arabic. This flexible language use created some 'camaraderie' (p. 125) between Mr S and the students. While students may have felt respected, valued and more included, Jaspers argued that this languaging practice also raised the students' awareness of language hierarchies. Given that the home languages were only used at transitional moments and in a playful way, they had less status. Furthermore, Hamman (2018) showed that the flexible language use in a primary dual-language class in the US led to children's unequal participation. The teachers and children used more English than Spanish which provided the English-dominant children with more opportunities to show their expertise and at times positioned the Spanish-dominant speakers as different. Finally, Mary and Young (2017) reported that a preschool teacher in France used translanguaging strategically to help children learn. The teacher used words and concepts in Turkish to show the three- to four-year-olds that she was knowledgeable of some cultural practices. This helped the children connect linguistic and cultural practices at home and at school. The resulting inclusive practice testifies 
to the teacher's intercultural competence 'underpinned by the value she places on equity and her consequent commitment to offer all the children in her care equal access to education' (Mary and Young 2017, p. 8). Taken together, Jaspers (2015), Hamman (2018), Mary and Young (2017) and Palviainen et al. (2016) seem to agree that teachers should carefully monitor their language use, that is plan how to use translanguaging strategically in teaching and learning in order to promote inclusion and ensure participation.

In sum, this section has shown that the translanguaging pedagogy intents to promote children's learning and participation through the inclusion of their entire linguistic and non-linguistic repertoires. Studies focusing on the relationship between translanguaging and inclusion in early education are scarce. Moreover, most studies either focused on one institutional language and the children's home languages (e.g. Belgium, France) or two institutional languages (e.g. Finland, Sri Lanka, US). Virtually no studies paid attention to the languaging practices of multilingual children and staff in contexts where two or more languages are used. The present study addresses these gaps and examines the translanguaging practices in a day-care center and a class of the édcuation précoce in multilingual Luxembourg in relation to inclusion. In order to examine if and how these practices are embedded in a reflexive translanguaging pedagogy that implies a more general inclusive stance (García et al. 2017), we ask:

- In what ways do practitioners deploy their linguistic repertoire?

- Why do they translanguage?

- To what extent does their translanguaging practice contribute to the inclusion and participation of all children?

\section{$3 \quad$ Methodology}

The present case study is part of the longitudinal research project MuLiPEC which examines the influence of a professional development course about multilingual pedagogies on the practitioners' knowledge, beliefs and practices (see Kirsch and Aleksić 2018). In this chapter, we focus on the practitioners of one formal and one non-formal education setting, who work with three-year-olds. Ms Clara (teacher) and Ms Jane (educator) work in an éducation précoce in a town in the South of Luxembourg and Mr Ken and Mr Ted are educators in a day-care center in the Center of Luxembourg. All four are aged between 30 and 39, have more than 10 years' experience and are multilingual. They all speak Luxembourgish, French, German, and English and Ms Clara and Mr Ken some Portuguese 
and Spanish respectively. The language diversity of the children was high in each setting. None of the 11 children in the précoce spoke Luxembourgish as a home language, but Arabic, Cape Verdean Créole, French, Portuguese, and Serbian/Croatian/Bosnian were spoken. While most children were from working class backgrounds in this school, most children in the day-care center were from middle-class families. Of the 21 children, most did not speak Luxembourgish as a home language but Arabic, Danish, English, Finnish, French, German, Portuguese, Russian, Spanish, and Serbian/Croatian/Bosnian were spoken.

The present chapter draws its data from 36 days of observations in the settings, 6 observations of the professional development course, and 11 interviews. A research assistant, Mortini ( $\mathrm{PhD}$ candidate), and Kirsch observed and video-recorded daily interactions. An overview of the activities is given in Table 1.

All video-recordings and interviews were transcribed and relevant paralinguistic resources (e.g. tone of voice) and extralinguistic resources (e.g. mime, gestures) were included in the observations. To analyse the translanguaging practices, Kirsch identified, firstly, monolingual and multilingual dialogues. Next, she analysed the deployment of the practitioners' and the children's linguistic resources in transglossic situations, examining which features of the repertoire were used and how these were orchestrated. Codes included using resources flexibly, translating and 'home languaging'. The first code refers to instances where adults and children dynamically combine various verbal and non-verbal resources from their repertoires to communicate in bi- or multilingual conversation. Translating means that specific key words or sentences are translated from Luxembourgish to another language or vice-versa. In other words, the same content is mentioned in two 'named' languages. Finally, the code 'home languaging' denotes situations of language separation where adults switched from Luxembourgish to a home language to talk to a particular child, thereby remaining in a monolingual mode. Thus, they may speak French to one child, German to another and Luxembourgish to the whole group, using one language with one person at the time. The categories may of course overlap and we distinguish them mainly for analytical purposes. In order to identify the nature and purpose of translanguaging, Kirsch made a micro-

Tab. 1 Overview of the type of language promoting activities

\begin{tabular}{l|l|l|l|l|l|l}
\hline $\mathrm{N}^{\circ}$ activities & Story-telling & $\begin{array}{l}\text { Language } \\
\text { activities }\end{array}$ & $\begin{array}{l}\text { Ritualised } \\
\text { activities }\end{array}$ & Singing & Art & $\mathrm{N}^{\circ}$ activities \\
\hline Précoce & 7 & 10 & 10 & 6 & 7 & 40 \\
\hline $\begin{array}{l}\text { Day-care } \\
\text { center }\end{array}$ & 7 & 10 & 4 & 4 & 3 & 28 \\
\hline
\end{tabular}


analysis of teacher talk (Seedhouse 2005), coding for communication, knowledge construction, well-being, inclusion/exclusion as well as interaction promoting strategies (e.g. asking questions) and language modelling strategies (e.g. corrective feedback). The findings generated from the video-recordings were compared across the two settings and triangulated with the interviews. The latter were analysed with thematic analysis (Braun and Clarke 2006) with a particular focus on the reasons for translanguaging and the relationship between translanguaging and inclusion.

\section{$4 \quad$ Findings and Discussion}

Languaging practices were, according to the practitioners, largely shaped by the traditional monolingual curriculum and the expectations of parents who had enrolled their children in the précoce or the day-care center to learn Luxembourgish. The practitioners explained that they had a habit of using Luxembourgish unless they needed to comfort a child during the settling-in-phase. Over the course of the professional development, they learned and experienced that translanguaging promoted language learning and did not confuse children (García 2009). Mr Ken explained that he felt good, 'almost freed' because he could let children communicate in their home languages without him having to ask 'do I have to intervene, do I have to insist on Luxembourgish?'. He believed that he could better accommodate children's needs. Ms Clara and Ms Jane similarly reported using home languages more frequently, feeling 'relieved' and 'less constrained' (interviews, March and June 2017). From February 2017, thus more than half a year into the professional development path, translanguaging became a legitimate practice in all settings (Kirsch et al. 2020). While all practitioners deployed features of several 'named' languages of their repertoire, they combined these in different ways. The following three sections present the orchestration of these linguistic resources in a more bilingual, monolingual and multilingual mode.

\subsection{Using Translations}

The practitioners in both settings regularly translated from Luxembourgish to a home language other than Luxembourgish and vice versa, across the different types of activities and for several purposes. Firstly, they translated key-words and sentences to facilitate communication, ensure comprehension and value home 
languages as shown elsewhere (Gort and Sembiante 2015; Mary and Young 2017; Lewis et al. 2013). Representative examples of both settings in Luxembourg follow. In October 2016, the children in the précoce mixed salt, flour and water to produce salt paste. When Abdul vigorously stirred the mixture, Ms Clara shouted in Luxembourgish 'lues' (slowly) which she translated into French ('doucement'), Abdul's home language. The translation ensured that Abdul understood the warning, which he may not have understood in Luxembourgish. In the day-care center, Mr Ken translated some words into English to engage an English-speaking child named Aaron during the sharing of a book on animals. In Excerpt 1, he pointed to a tiger and Paul, a Luxembourgish-speaking child, mentioned that it was friendly. Mr Ken asked Paul if it looked friendly (line 2). Aaron uttered 'not friendly' in Luxembourgish, disagreeing with Paul (line 3). Mr Ken translated these two words into English and turned them into a clarification question (line 4). Aaron confirmed in Luxembourgish that the tiger was not friendly without any further elaboration.

\begin{tabular}{|l|l|l|l|}
\hline & Actor & $\begin{array}{l}\text { Original utterance (Luxembourgish, } \\
\text { English }\end{array}$ & English translation \\
\hline 1 & Paul & Awer 't ass ee léiwen Tiger. & But it is a friendly tiger. \\
\hline 2 & Mr Ken & $\begin{array}{l}\text { Wéi weess du dann, dass ee léif ass? } \\
\text { Kuckt e léif? }\end{array}$ & $\begin{array}{l}\text { How do you know that it is friendly? } \\
\text { Does it look friendly? }\end{array}$ \\
\hline 3 & Aaron & Net léif. & Not friendly. \\
\hline 4 & Mr Ken & Not nice? & Not nice? \\
\hline 5 & Aaron & Nee. & No. \\
\hline
\end{tabular}

Excerpt 1 Book on animals (07.11.2016)

Secondly, translating was used to promote language learning. When teaching key words, Ms Clara and Ms Jane translated these to help children understand and memorise the words by encoding them in two languages. Furthermore, they regularly translated from Portuguese or French into Luxembourgish to help children follow a conversation and encourage their participation. During a storytelling activity in February 2017 (Excerpt 2), for example, three-year-old Sarah described a picture in Portuguese, which led Ms Clara to translate the child's utterance into Luxembourgish. This translation legitimised the use of Portuguese in class and enabled the non-Portuguese children to understand Sarah's contribution. Ms Clara then extended the sentence to provide additional input in Luxembourgish. 


\begin{tabular}{|l|l|l|}
\hline Actor & $\begin{array}{l}\text { Original utterance } \\
\text { (Luxembourgish, Portuguese) }\end{array}$ & English translation \\
\hline Sarah & Tem livros na cabeça. & It has books in his head. \\
\hline Ms Clara & $\begin{array}{l}\text { Deen huet Bicher um Kapp. An dann } \\
\text { probéiert hien ze trëppelen, mee dat } \\
\text { ass schwéier. }\end{array}$ & $\begin{array}{l}\text { He has books on his head. And then he tries } \\
\text { to walk but this is difficult. }\end{array}$ \\
\hline
\end{tabular}

Excerpt 2 Storytelling activity, book project (06.02.2017)

Translating is one of many communication strategies, as illustrated in the following example of Ms Clara. During one morning circle in February 2017, for example, when the children routinely counted all children, then the boys and the girls in turn, Abdul became confused. Rather than counting the boys, he counted the girls. Ms Clara repeated the Luxembourgish word for boys and made a 'no' gesture with her fingers, when Abdul began to count the girls a second and a third time. She then translated the word 'boy' into French, but realising that Abdul did still not know what to do, she showed him a picture of a boy and repeated the Luxembourgish word, articulating it slowly and carefully. Abdul finally understood his task. This example shows that Ms Clara orchestrated many resources of her multimodal semiotic repertoire (Blackledge et al. 2017; García and Otheguy 2019). Translating, a bilingual strategy, did not suffice to help Abdul understand the word 'boy'. Given that young children are in the process of developing concepts, they need to experience word meanings in a wider range of ways and teacher-led translanguaging can therefore contribute to meaning-making.

There were plentiful examples of translating for the purpose of learning words in the day-care center. Excerpt 3 shows Gaspard saying 'knife' in French and $\mathrm{Mr}$ Ken translating the word into Luxembourgish and praising Gaspard. In Excerpt 4, Tony mentioned a colour in Luxembourgish, which Mr Ken translated for Gaspard into French.

\begin{tabular}{|l|l|l|l|}
\hline Actor & Description & $\begin{array}{l}\text { Original utterance } \\
\text { (Luxembourgish, French) }\end{array}$ & English translation \\
\hline Gaspard & Taking a knife & Couteau & Knife \\
\hline Mr Ken & Pointing & $\begin{array}{l}\text { Mat engem Messer. Richteg } \\
\text { Gaspard, super. }\end{array}$ & $\begin{array}{l}\text { With a knife. Correct, Gaspard, } \\
\text { super. }\end{array}$ \\
\hline
\end{tabular}

Excerpt 3 Conversation over lunch (09.01.2017) 


\begin{tabular}{|l|l|l|l|}
\hline Actor & Description & $\begin{array}{l}\text { Original utterance } \\
\text { (Luxembourgish, French) }\end{array}$ & English translation \\
\hline Tony & & Gréng & Green \\
\hline Mr Ken & To Gaspard & Vert & Green \\
\hline
\end{tabular}

Excerpt 4 Language activity (19.06.2017)

The educators in the day-care center had developed the practice of asking children for labels and translations, unlike the practitioners in the précoce. Excerpt 5 is drawn from the activity with the animal book (November 2016). Turning to Aaron, Mr Ken switched from Luxembourgish to English and asked if he had seen a fox (line 1). Aaron pointed to one. Switching back to Luxembourgish, $\mathrm{Mr}$ Ken asked for a translation of 'fox' (line 3). Aaron said daddy in Luxembourgish, expressing the idea that the fox is male. Mr Ken repeated his question and Aaron responded in Luxembourgish that he did not know. Aurélie created a Luxembourgish compound to indicate that the fox was female. She thereby challenged Aaron.

\begin{tabular}{|l|l|l|l|}
\hline & Actor & $\begin{array}{l}\text { Original utterance } \\
\text { (Luxembourgish, English) }\end{array}$ & English translation \\
\hline 1 & Mr Ken & $\begin{array}{l}\text { Aaron, have you seen? Where is } \\
\text { the fox? }\end{array}$ & $\begin{array}{l}\text { Aaron, have you seen? Where is the } \\
\text { fox? }\end{array}$ \\
\hline 2 & Aaron & (pointing) & (pointing) \\
\hline 3 & Mr Ken & $\begin{array}{l}\text { Wéi heescht deen dann? Wéi } \\
\text { nenne mir deen? }\end{array}$ & What is it called? What do we call it? \\
\hline 4 & Aaron & Papa & Daddy \\
\hline 5 & Mr Ken & $\begin{array}{l}\text { A wéi soe mir op } \\
\text { Lëtzebuergesch? }\end{array}$ & $\begin{array}{l}\text { And how do you say in } \\
\text { Luxembourgish? }\end{array}$ \\
\hline 6 & Aaron & Ech weess net. & I don't know. \\
\hline 7 & Aurélie & Nee, 't ass ee Mamafuuss. & No, it is a mummy fox. \\
\hline
\end{tabular}

Excerpt 5 Book on animals (07.11.2016)

An analysis of the classroom discourse revealed that the practitioners in the school setting used different interaction promoting strategies and engaged children differently from the practitioners in the day-care center. Mr Ken and Mr Ted tended to work at the word-level, believing that three-year-olds develop languages in stages and are at the word-level stage (interview, September 2016). This may explain their focus on label quests and translations (Excerpts 1, 3, 4, 5). They tended to use closed questions to stimulate talk but rarely used modelling strategies such 
as corrective feedback and extensions unlike Ms Clara and Ms Jane (Excerpt 2). Another difference is the 'automatic' use of translations. $\mathrm{Mr}$ Ken and $\mathrm{Mr} \mathrm{Ted}$ explained that they wished all children to feel well and included, and that the use of the children's home language contributed to this aim. However, the purpose of their translations was not always clear: they translated when there was no apparent need and no signs of misunderstanding. Aaron spoke Luxembourgish (Excerpts 1, 5) and Gaspard was able to speak Luxembourgish in June 2017 (Excerpt 4) but the educators translated nevertheless. Ms Clara and Ms Jane, by contrast, used translating more purposefully and in combination with other strategies, which would suggest a more careful monitoring both of the children's needs and their own language use (García 2009; Palviainen et al. 2016).

\subsection{Home Languaging}

At the beginning of the academic year, all practitioners switched from Luxembourgish to a home language within an otherwise Luxembourgish space for communicative purposes other than translating words. This practice happened across activities and was legitimated by the intention to contribute to children's well-being (see also Seele 2016).

[Using home languages] is particularly important at the beginning of a school year to ensure that children feel well, accepted and understood. Furthermore, they are less afraid if we explain something in their language and request something. They develop a sense of security. Slowly, you then add Luxembourgish.

(Interview Ms Clara and Ms Jane, 9.9.2016)

The idea that the use of home languages is helpful and legitimate in the early stages but then needs to be replaced, as seen in the interview excerpt, was expressed by all practitioners. Through the professional development path, they became aware of the relationship between home language, well-being, identity and language learning and therefore continued to use home languages during the whole academic year (Cummins 2000; Mary and Young 2017; Kirsch 2017). This was particularly the case when they wanted to comfort or discipline a child or ensure comprehension. While working on an assessment task at the end of the school year in June 2017, Ms Jane switched from Luxembourgish to Portuguese to accommodate for Sandro's linguistic needs. She explained the task in Portuguese to be sure he understood. As seen previously, Mr Ken switched to English to address Aaron (Excerpts 1 and 5) and to French to address Gaspard (Excerpt 4). Excerpt 6 illustrates a similar switch to French by Mr Ted to address Gaspard during an outdoor play activity. 
Gaspard sat in a huge box, playing on his own. Mr Ted approached him, sat in front of the box and tried to engage him in a conversation. He put a card box piece on top of the box and called Gaspard. Gaspard looked up but did not speak. Mr Ted switched to French asking him to use the board to make a window. When Gaspard did not react verbally, Mr Ted built a 'window' himself and tried to play peekaboo (line 1). Gaspard looked up but did not react. Mr Ted put more pieces close to the box, encouraging Gaspard to build a window (line 3). Gaspard did not react. When Nadia arrived, Mr Ted switched back to Luxembourgish, asking if she wanted to get into the box and informing her that they were building a window (line 5). $\mathrm{He}$ then called Gaspard, asking him to look. The conversation shifted from monolingual French (lines 1,3) to monolingual Luxembourgish (line 5).

\begin{tabular}{|c|c|c|c|c|}
\hline & Actor & Description & $\begin{array}{l}\text { Original utterance } \\
\text { (Luxembourgish, } \\
\text { French) }\end{array}$ & English translation \\
\hline 1 & Mr Ted & $\begin{array}{l}\text { Building } \\
\text { window }\end{array}$ & $\begin{array}{l}\text { Fais une fenêtre! } \\
\text { Gaspard, regarde. Tu } \\
\text { peux voir? Bonjour. } \\
\text { Bonjour. }\end{array}$ & $\begin{array}{l}\text { Build a window! Gaspard, } \\
\text { look. Can you see? Good } \\
\text { morning. Good morning. }\end{array}$ \\
\hline 2 & Gaspard & looking & & \\
\hline 3 & Mr Ted & $\begin{array}{lr}\text { Taking } & \text { more } \\
\text { pieces and } \\
\text { putting them } \\
\text { close to the box }\end{array}$ & $\begin{array}{l}\text { Encore une fenêtre. Tu } \\
\text { veux? Gaspard, tu veux } \\
\text { une fenêtre? }\end{array}$ & $\begin{array}{l}\text { Another window. Do you } \\
\text { want? Gaspard, do you want } \\
\text { a window? }\end{array}$ \\
\hline 4 & Nadia & arrives & & \\
\hline 5 & Mr Ted & & $\begin{array}{l}\text { Gees du och an } \\
\text { d'Këscht Nadia? Mir } \\
\text { maachen eng Fënster. } \\
\text { Gaspard, kuck. }\end{array}$ & $\begin{array}{l}\text { Will you go into the box as } \\
\text { well, Nadia? We build a } \\
\text { window. Gaspard, look. }\end{array}$ \\
\hline
\end{tabular}

Excerpt 6 Outdoor play (27.03.2017)

The switch to French was intended to engage Gaspard in a conversation but $\mathrm{Mr}$ Ted did not succeed. Gaspard played happily on his own and did not wish to engage, notwithstanding the use of the home language or the number of prompts. This excerpt illustrates the educators' adult-centerd way of interacting without paying close attention to the child's linguistic, social or emotional interests. Many observations revealed that the educators seemed to find it difficult to observe or carefully listen to children, let them take a lead, and engage them in a meaningful way. By addressing children in their home language while they tried to communicate in the language of the institution, the educators may well have 'othered' these children (Thomauske 2017). 


\subsection{Using Resources Flexibly and Dynamically}

Children in both settings were observed combining features of their semiotic repertoire in flexible ways to communicate. By contrast, we observed mainly the practitioners in the précoce orchestrate their linguistic as well as paralinguistic and extralinguistic resources in dynamic ways. A first example presented was the observation of Abdul counting boys. This fluid translanguaging practice was observed in most activities from the second term onwards once the children had developed more skills in Luxembourgish and Ms Jane in Portuguese. Both practitioners seemed to have opened up to multilingual education and developed a translanguaging stance. Excerpt 7 illustrates Ms Clara and Felice translanguaging while looking at a book during free-play. This excerpt is typical of situations of dialogic reading in this classroom and illustrates how adults and children weaved together multimodal and multilingual resources to communicate, negotiate meaning and ensure comprehension. In this particular dialogue, only two people participate. Moving easily between Luxembourgish, Portuguese and English and using the whole body enabled Ms Clara and Felice to co-construct meaning. The three-year old boy pointed to details in the picture, labelled the animals in Portuguese (lines 1, 5), and used English (line 3) or Luxembourgish with Portuguese (lines 7,11$)$ to make himself understood. To guarantee comprehension, he pointed and imitated the slithering movement of a snake. The teacher listened to Felice and confirmed (lines 2,4) or corrected his speech (line 6) when he confused snakes with worms. To help Felice remember the names of the animals and the word 'heart', she pointed to the objects in the book, drew a heart on his chest to make him feel the shape (line 12), repeated words (lines $4,6,8$ ) and translated (lines 2, 4, 6, 10). As Felice did not know the word ladybird, she offered him the word in Luxembourgish and Portuguese. Felice not only had an opportunity to acquire the Luxembourgish names of the animals he knew in Portuguese but he may also have learned more about a grasshopper, a snake and a ladybird. Ms Clara showed him the grasshopper he had not mentioned and provided some explanations (line 2). She also rephrased his short utterances and embedded them in slightly larger chunks (line 8,12 ) to promote language learning. In contrast to Excerpt 6 of the day-care center, Ms Clara monitored her speech and was highly responsive to the child's interests and needs. She let Felice take the lead, provided input when necessary to move the conversation on, translated with a purpose in mind and created a space where both could use their entire semiotic repertoire 
for meaning-making. The range of strategies deployed, such as translations, repetitions, explanations, questions, corrective feedback, pointing and drawing are very similar to the strategies used by other teachers (e.g. Mary and Young 2017; Mifsud and Vella 2018). In this carefully scaffolded child-initiated interaction, Ms Clara posits both herself and the child as multilingual. This positioning, which includes and legitimates the child's language practices, may enhance the child's confidence and well-being and make him feel valued and included in class. It is a core strategy of a translanguaging pedagogy according to Palmer et al. (2014).

\begin{tabular}{|c|c|c|c|c|}
\hline & Actor & Description & $\begin{array}{l}\text { Utterance (Luxembourgish, } \\
\text { Portuguese, English) }\end{array}$ & English translation \\
\hline 1 & Felice & pointing & Caracol & Snail. \\
\hline 2 & Ms Clara & pointing & $\begin{array}{l}\text { Jo, do ass e Schleek. } \\
\text { En Heesprenger, gell, de } \\
\text { sprengt. }\end{array}$ & $\begin{array}{l}\text { Yes, this is a snail. A } \\
\text { grasshopper, it jumps, } \\
\text { doesn't it? }\end{array}$ \\
\hline 3 & Felice & pointing & Oh, another one. & Oh, another one. \\
\hline 4 & Ms Clara & & Nach een. Schleek. & Another one. Snail. \\
\hline 5 & Felice & $\begin{array}{l}\text { slithering } \\
\text { like a snake } \\
\text { on the floor }\end{array}$ & Oh, cobra. & Uh, snake. \\
\hline 6 & Ms Clara & & $\begin{array}{l}\text { Nee, et ass keng Schlaang, et } \\
\text { ass e Wuerm. Et ass e Wuerm. }\end{array}$ & $\begin{array}{l}\text { No, it is not a snake, it is a } \\
\text { worm. It is a worm. (...) }\end{array}$ \\
\hline 7 & Felice & $\begin{array}{l}\text { pointing to a } \\
\text { ladybird }\end{array}$ & $\mathrm{Uh}$, roud $e$ schwaarz. & Uh, red and black. \\
\hline 8 & Ms Clara & & $\begin{array}{l}\text { Et ass roud mat schwaarze } \\
\text { Punkte, mee wéi heescht } \\
\text { deen? }\end{array}$ & $\begin{array}{l}\text { It is red and has black dots } \\
\text { but what is it called? }\end{array}$ \\
\hline 9 & Felice & & Eu пão sei o que é. & I do not know what it is. \\
\hline 10 & Ms Clara & & $\begin{array}{l}\text { Ah, weess du et net? Dat ass } \\
\text { en Himmelsdéierchen. } \\
\text { Joaninha. (...) }\end{array}$ & $\begin{array}{l}\text { Uh, you do not know? That } \\
\text { is a ladybird. A ladybird. }\end{array}$ \\
\hline 11 & Felice & $\begin{array}{l}\text { pointing to a } \\
\text { heart }\end{array}$ & En huet en coração. & He has a heard. \\
\hline 12 & Ms Clara & $\begin{array}{l}\text { drawing a } \\
\text { heart on his } \\
\text { chest }\end{array}$ & $\begin{array}{l}\text { Jo, en hued en Häerz um } \\
\text { Bauch. }\end{array}$ & $\begin{array}{l}\text { Yes, he has a heart on his } \\
\text { belly. }\end{array}$ \\
\hline
\end{tabular}

Excerpt 7 Book reading in the précoce (04.07.2017) 


\section{Summary and Conclusions}

Focusing on practitioners in early childhood education in Luxembourg, this chapter set out to analyse their reasons for translanguaging, the deployment of their linguistic repertoire, and the ways in which their practice contributed to inclusion and participation. The results showed that all four practitioners associated translanguaging with particular aims such as communication, learning, participation, well-being and recognition of home languages (García 2011; Garrity et al. 2015; Gort and Sembiante 2015; Kirsch 2017). Furthermore, we found that all practitioners, who adhered to monolingual policies at the beginning of the professional development path, began to deploy their multilingual and multimodal repertoires more flexibly. This encouraged children to use language features dynamically. Translanguaging became a legitimate practice. The adults' multilingual language practices included translating, 'home languaging' and, especially in the case of the précoce, using semiotic resources flexibly and fluidly. Like teachers elsewhere (Gort and Sembiante 2015; Mary and Young 2017; Palviainen et al. 2016), the practitioners in Luxembourg frequently deployed translations. Unlike other studies, they also reverted to various home languages for purposes other than translations. To ensure their well-being, they at times addressed children in their home languages, speaking one language to one child, a second to the other. In this way, they created a situation of parallel monolingualism. This practice of frequent switching testifies to the practitioners' multilingual competence and is typical of residents in Luxembourg who need to constantly accommodate the interlocutors' linguistic needs in this highly diverse country. Similar to the Welsh study (Lewis et al. 2013), the translanguaging practices in Luxembourg developed with the children's (and the practitioners') developing language competence.

There were some differences in the translanguaging practices between the practitioners. Ms Clara and Ms Jane engaged less in 'home languaging' and used their semiotic repertoires more fluidly, as a result of having developed a dynamic view of multilingualism (García 2009). Furthermore, they monitored children's linguistic needs more carefully than the practitioners in the day-care center, possibly because of their longer experience of observing and assessing children at the end of each term or the teacher education programme, which focuses on planning, teaching, assessment and reflection on one's practice. Ms Clara and Ms Jane had come to deploy translanguaging as part of a pedagogy including design and stance (García et al. 2017), thus legitimating and making 'visible the meaning-making potential of all students' (García and Otheguy 2019, p. 11). In doing so, they helped all children participate in daily interactions and 
literacy activities. By contrast, $\mathrm{Mr}$ Ken and $\mathrm{Mr}$ Ted tended to use translating and 'home languaging' to accommodate for the perceived needs of the children without always considering their actual needs or reflecting how this may enhance their participation. There were some examples of unequal participation and 'othering' (Hamman 2018; Thomauske 2017), possibly because the multilingual practices were not embedded into a translanguaging pedagogy.

With the limited data at hand, we do not claim that the practices we observed in the day-care center led to exclusion. But, based on our findings, we wish to remind practitioners and researchers that we need to take a close look at the forms of flexible language use, and their implications. Translanguaging can be inclusive and encourage participation if practitioners use their linguistic repertoires strategically and based on children's needs, and if they are aware of language hierarchies (Jaspers 2015; Hamman 2018). We therefore agree that translanguaging practices need to be integrated into a wider transformative pedagogy that values social justice and inclusion (García et al. 2017). While we agree with the need to monitor languages as emphasised by García (2009) or Palviainen et al. (2016), our findings have shown that this complex ability does not come automatically, and may need to be developed, for example through further training with a focus on observation and reflection. Future research could examine factors beyond the adults' languaging practices, such as the children's views, policy frameworks, the institutional context and parental contributions.

\section{References}

Blackledge, A., Creese, A., \& Hu, R. (2017). Translanguaging, Volleyball and Social Life. Working Papers in Translanguaging and Translation, WP 19. http://www.birmingham. ac.uk/generic/tlang/index.aspx. Accessed: August 23rd 2019.

Booth, T., Ainskow, M., \& Kingston, D. (2008). Index for Inclusion. Developing Play, Learning and Participation in Early Years and Childcare. Bristol: CSIE.

Braun, V., \& Clarke, V. (2006). Using thematic analysis in psychology. Qualitative Research in Psychology 3(2), 77-101.

Christmann, N. (2011). Der Vielfalt (k)eine Chance geben: Zur Rolle der Mehrsprachigkeit im pädagogischen Alltag einer luxemburgischen Vor- und Grundschule. In: I. Diehm, \& A. Panagiotopoulou (Eds.), Bildungsbedingungen in europäischen Migrationsgesellschaften: Ergebnisse qualitativer Studien in Vor- und Grundschule (pp. 73-83). Wiesbaden: VS Verlag für Sozialwissenschaften.

Cummins, J. (2000). Language, Power, and Pedagogy. Bilingual Children in the Crossfire. Clevedon: Multilingual Matters. 
European Commission (2011). Language Learning at Pre-primary School Level. Making it Efficient and Sustainable. A Policy Handbook. https://ec.europa.eu/education/ sites/education/files/document-library-docs/early-language-learning-handbook_en.pdf. Accessed: August 22nd 2019.

Fehlen, F., \& Heinz, A. (2016). Die Luxemburger Mehrsprachigkeit. Ergebnisse einer Volkszählung. Bielefeld: transcript.

García, O. (2009). Bilingual Education in the 21st Century. A Global Perspective. Malden: Wiley/Blackwell.

García, O. (with Makar, C., Starcevic, M., \& Terry, A.) (2011). Translanguaging of Latino kindergarteners. In: K. Potowski, \& J. Rothman (Eds.), Bilingual Youth. Spanish in English Speaking Societies (p. 33-55). Amsterdam: John Benjamins.

García, O., \& Flores, N. (2012). Multilingual pedagogies. In: M. Martin-Jones, A. Blackledge, \& A. Creese (Eds.), The Routledge Handbook of Multilingualism (p. 232-246). New York: Routledge.

García, O., \& Li Wei (2014). Translanguaging. Language, Bilingualism and Education. New York: Palgrave Macmillan.

García, O., \& Otheguy, R. (2019). Plurilingualism and translanguaging: commonalities and divergences. International Journal of Bilingual Education and Bilingualism. https://doi. org/10.1080/13670050.2019.1598932.

García, O., Flores, N., \& Woodley, H. M. (2012). Transgressing monolingualism and bilingual dualities: translanguaging pedagogies. In: A. Yiakoumetti (Ed.), Harnessing Linguistic Variation to Improve Education (p. 45-75). Bern: Peter Lang.

García, O., Johnson, S. I., \& Seltzer, K. (2017). The Translanguaging Classroom. Leveraging Student Bilingualism for Learning. Philadelphia: Caslon.

Garrity, S., Aquino-Sterling, C. R., \& Day, A. (2015). Translanguaging in an infant classroom. Using multiple languages to make meaning. International Multilingual Research Journal 9, 177-196.

Gort, M., \& Sembiante, S. F. (2015). Navigating hybridized language learning spaces through translanguaging pedagogy. Dual language preschool teachers' languaging practices in support of emergent bilingual children's performance of academic discourse. International Multilingual Research Journal 9, 7-25.

Hamman, L. (2018). Translanguaging and positioning in two-way dual language classrooms. A case for criticality. Language and Education 32(1), 21-42.

Jaspers, J. (2015). Modelling linguistic diversity at school. The excluding impact of inclusive multilingualism. Language Policy 14(2), 109-129.

Kirsch, C. (2017). Young children capitalising on their entire language repertoire for language learning at school. Language, Culture and Curriculum 31(1), 39-55.

Kirsch, C., \& Aleksić, G. (2018). The effect of professional development on multilingual education in early childhood in Luxembourg. Review of European Studies 10(4), 148-163.

Kirsch, C., \& Seele, C. (2020). Early language education in Luxembourg. In: M. Schwartz (Ed.), International Handbook of Early Language Education (online only). Dordrecht: Springer.

Kirsch, C., Aleksić, G., Mortini, S., \& Andersen, K. N. (2020). Developing multilingual practices in early childhood education through a professional development in Luxembourg. International Multilingual Research Journal. https://doi.org/10.1080/19313152.2 020.1730023 . 
Lewis, G., Jones, B., \& Baker, C. (2013). 100 bilingual lessons. Distributing two languages in 501 classrooms. In: C. Abello-Contesse, \& R. Chacón Beltrán (Eds.), Bilingualism in a School Setting (p. 107-135). Bristol: Multilingual Matters.

Mary, L., \& Young, A. S. (2017). Engaging with emergent bilinguals and their families in the pre-primary classroom to foster well-being, learning and inclusion. Language and Intercultural Communication 17(4), 455-473.

MENJE (Ministère de l'Éducation nationale, de l'Enfance et de la Jeunesse) (2018). Information about the PISA Study 2018. Luxembourg: MENJE.

MENJE (Ministère de l'Éducation nationale, de l'Enfance et de la Jeunesse) (2019). Enseignement fondamental. Education différenciée. Statistiques globales et analyses des résultats scolaires. Luxembourg: MENJE.

MENJE \& SNJ (Ministère de l'Éducation nationale, de l'Enfance et de la Jeunesse \& Service National de la Jeunesse, Luxembourg) (2018). Cadre de référence national sur l'éducation non formelle des enfants et des jeunes. Luxembourg: MENJE \& SNJ.

Mifsud, C. L., \& Vella, A. L. (2018). To mix languages or not? Preschool bilingual education in Malta. In: M. Schwartz (Ed.), Preschool Bilingual Education. Agency in Interactions between Children, Teachers, and Parents (p. 57-98). Dordrecht: Springer.

MFI \& SNJ (Ministère de la Famille et de l'Intégration \& Service National de la Jeunesse, Luxembourg) (2013). Non-Formal Education with Children and Young People. Learning in Out-of-School Settings. Luxembourg: SNJ.

Neumann, S. (2015). Lost in translanguaging? Practices of language promotion in Luxembourgish early childhood education. Global Education Review 2(1), $23-39$.

Palmer, D. K., Martínez, R. A., Mateus, S. G., \& Henderson, K. (2014). Reframing the debate on language separation. Toward a vision for translanguaging pedagogies in the dual language classroom. The Modern Language Journal 98(3), 757-772.

Palviainen, Å., Protassova, E., Mård-Miettinen, K., \& Schwartz, M. (2016). Two languages in the air. A cross-cultural comparison of preschool teachers' reflections on their flexible bilingual practices. International Journal of Bilingual Education and Bilingualism 19(6), 614-630.

Seedhouse, P. (2005). Conversation Analysis and language learning. Language Teaching 38(4), 165-187.

Seele, C. (2016). 'Doing Education' Between Monolingual Norms and Multilingual Realities: An Ethnography of Multilingualism in Early Childhood Education and Care. Stroud: E\&E Publishing.

Skutnabb-Kangas, T. (Ed.). (1995). Multilingualism for All. Volume 4: European Studies on Multilingualism. Lisse: Swets \& Zeitlinger.

STATEC (Institut national de la statistique et des études économiques du Grand-Duché de Luxembourg) (2019). Population structure. Luxembourg: STATEC.

Thomauske, N. (2017). Sprachlos gemacht in Kita und Familie: Ein deutsch-französischer Vergleich von Sprachpolitiken und -praktiken. Wiesbaden: Springer VS.

UNESCO (United Nations Educational, Scientific and Cultural Organization) (2009). Policy Guidelines on Inclusion in Education. Paris: UNESCO. https://unesdoc.unesco.org/ ark:/48223/pf0000177849. Accessed: August 22nd 2019. 
Weber, J.-J. (2014). Flexible Multilingual Education. Putting Children's Needs First. Bristol: Multilingual Matters.

Wijesekera, H. D., Alford, J., \& Mu, M. G. (2018). Forging inclusive practice in ethnically-segregated school systems. Lessons from one multiethnic, bilingual education classroom in Sri Lanka. International Journal of Inclusive Education 23(1), 23-41.

Open Access This chapter is licensed under the terms of the Creative Commons Attribution 4.0 International License (http://creativecommons.org/licenses/by/4.0/), which permits use, sharing, adaptation, distribution and reproduction in any medium or format, as long as you give appropriate credit to the original author(s) and the source, provide a link to the Creative Commons license and indicate if changes were made.

The images or other third party material in this chapter are included in the chapter's Creative Commons license, unless indicated otherwise in a credit line to the material. If material is not included in the chapter's Creative Commons license and your intended use is not permitted by statutory regulation or exceeds the permitted use, you will need to obtain permission directly from the copyright holder.

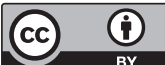

